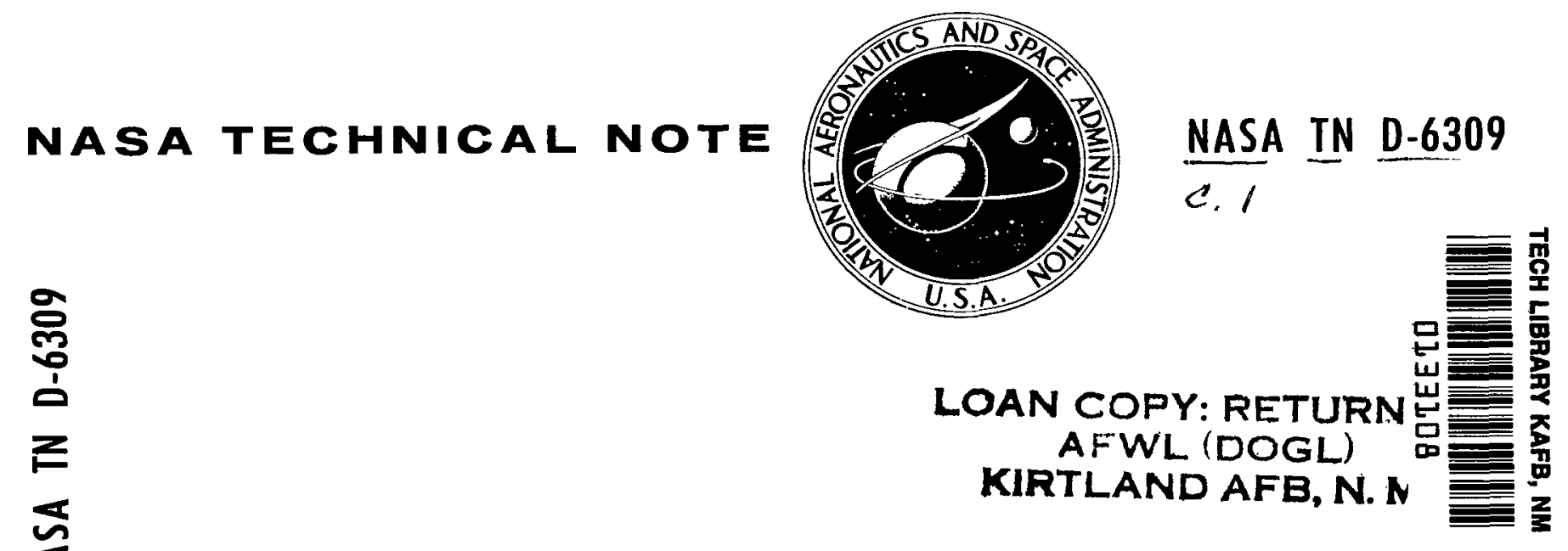

CYCLIC CREEP-RUPTURE BEHAVIOR

OF THREE HIGH-TEMPERATURE ALLOYS

by Gary R. Halford

Lewis Research Center

Cleveland, Obio 44135

national aeronautics and Space administration - Washington, D. C. - MaY 1971 


\begin{tabular}{|c|c|}
\hline \begin{tabular}{l|l} 
1. Report No. & 2. Government Accession No. \\
NASA TN D-6309 &
\end{tabular} & 3. Recipient's Catalog No. \\
\hline \multirow{2}{*}{$\begin{array}{l}\text { 4. Title and Subtitle } \\
\text { CYCLIC CREEP-RUPTURE BEHAVIOR OF THREE } \\
\text { HIGH-TEMPERATURE ALLOYS }\end{array}$} & $\begin{array}{l}\text { 5. Report Date } \\
\text { May } 1971\end{array}$ \\
\hline & 6. Performing Organization Code \\
\hline $\begin{array}{l}\text { 7. Author(s) } \\
\text { Gary R. Halford }\end{array}$ & $\begin{array}{l}\text { 8. Performing Organization Report No. } \\
\text { E-6062 }\end{array}$ \\
\hline \multirow{2}{*}{$\begin{array}{l}\text { 9. Performing Organization Name and Address } \\
\text { Lewis Research Center } \\
\text { National Aeronautics and Space Administration } \\
\text { Cleveland, Ohio } 44135\end{array}$} & $\begin{array}{l}\text { 10. Work Unit No. } \\
129-03\end{array}$ \\
\hline & \multirow{2}{*}{$\begin{array}{l}\text { 11. Contract or Grant No. } \\
\text { 13. Type of Report and Period Covered } \\
\text { Technical Note }\end{array}$} \\
\hline \multirow{2}{*}{$\begin{array}{l}\text { 12. Sponsoring Agency Name and Address } \\
\text { National Aeronautics and Space Administration } \\
\text { Washington, D. C. } 20546\end{array}$} & \\
\hline & 14. Sponsoring Agency Code \\
\hline
\end{tabular}

15. Supplementary Notes

16. Abstract

A series of cyclic creep-rupture tests were conducted on three high-temperature alloys, titanium-6Al-2Sn-4Zr-2Mo, the cobalt-base alloy L-605, and 316 stainless steel, over a range of operating conditions. The results substantiate previous assumptions that the cyclic creep-rupture curve is indeed independent of the total strain range and the level of compressive stress employed. The cyclic creep-rupture curve therefore represents a unique relation between tensile stress and tensile time-to-rupture for strain-limited cyclic loading. The cyclic creep-rupture curves were found to lie above and to the right of the conventional (constant load) monotonic curves by factors ranging from 2 to 20 in rupture time. Cyclic creep acceleration and differences between tensile and compressive creep rates were also observed.

17. Key Words (Suggested by Author(s))

Cyclic creep; Creep fatigue damage; Creep rupture strength; Creep ductility; Strain fatigue; High temperature materials; PalmgrenMiner rule; Compressive creep; Tensile creep; Stainless steels; Titanium alloys; Cobalt alloys
18. Distribution Statement Unclassified - unlimited

\begin{tabular}{|c|c|c|c|}
\hline $\begin{array}{c}\text { 19. Security Classif. (of this report) } \\
\text { Unclassified }\end{array}$ & $\begin{array}{c}\text { 20. Security Classif. (of this page) } \\
\text { Unclassified }\end{array}$ & $\begin{array}{c}\text { 21. No. of Pages } \\
22 .\end{array}$ & $\begin{array}{c}\text { Price } \\
\$ 3.00\end{array}$ \\
\hline
\end{tabular}

\footnotetext{
*For sale by the National Technical Information Service, Springfield, Virginia 22151
} 


\title{
CYCLIC CREEP-RUPTURE BEHAVIOR OF THREE HIGH-TEMPERATURE ALLOYS
}

\author{
by Gary R. Halford
}

\author{
Lewis Research Center
}

\section{SUMMARY}

Some important characteristics of the cyclic creep-rupture curves have been studied for the titanium alloy $6 \mathrm{Al}-2 \mathrm{Sn}-4 \mathrm{Zr}-2 \mathrm{Mo}$ at $900^{\circ}$ and $1100^{\circ} \mathrm{F}(755$ and $865 \mathrm{~K})$, the cobaltbase alloy $\mathrm{L}-605$ at $1180^{\circ} \mathrm{F}(910 \mathrm{~K})$, and for two hardness levels of 316 stainless steel at $1300^{\circ} \mathrm{F}(980 \mathrm{~K})$. Such curves have been used successfully in a previous investigation for the evaluation and prediction of strain-cycling life at elevated temperatures within the creep range. The cyclic creep-rupture curve relates tensile stress and tensile timeto-rupture for strain-limited cyclic loading and has been found to be independent of the total strain range and the level of compressive stress employed in the cyclic creeprupture tests. Thus, the cyclic creep-rupture curve represents not only a useful, but a unique, failure criterion for strain-limited, cyclic loading.

The cyclic creep-rupture curve was always found to be above and to the right of the conventional (constant load) monotonic creep-rupture curve by factors ranging from 2 to 20 in time-to-rupture. This factor tends to be greatest when the creep ductility is large.

Cyclic creep acceleration was observed in every cyclic creep-rupture test conducted. The phenomenon was most pronounced at the highest stress levels and when the tensile and compressive stresses were completely reversed.

In general, creep rates were found to be lower in compression than in tension for equal true stresses. The differences, however, were strongly material dependent.

\section{INTRODUCTION}

Over the past few years, we at the Lewis Research Center have been developing methods for analyzing and predicting the resistance of materials to failure by cyclic loading at elevated temperatures in the high-strain, low-cycle range (refs. 1 to 6). The term failure by cyclic loading is used instead of fatigue since, as is often the case, 
failures encountered at high-temperature bear little or no resemblance to classical fatigue failures.

Instead of being transgranular, cracks frequently follow grain boundaries - a mechanism of failure normally associated with creep-rupture. In fact, the procedure for life analysis and prediction that we have found to be the most promising to date is based on the supposition that failures are governed by the accumulation of cyclic creep-rupture damage at the one extreme or by the accumulation of fatigue damage at the other (paper by S. Manson, G. Halford, and D. Spera of Lewis Research Center to be published in the A. E. Johnson Memorial Volume; A. S. Smith, ed. ; Elsevier Publishing Company Ltd.). In general, the failures result from some combination of these two damaging mechanisms, depending on the specific combination of imposed stress, strain, and temperature, and on their respective time rates of change. A simple linear creep - fatigue-damage rule as proposed by Taira (ref. 7) is used as a vehicle for evaluating the relative contributions of each damaging mechanism. Fatigue damage is represented by cycle ratios as suggested by Palmgren (ref. 8), Langer (ref. 9), and Miner (ref. 10). Manson's equation of universal slopes (ref. 11) is used to determine the pure fatigue failure criterion. Creeprupture damage is represented by time ratios, as suggested by Robinson (ref. 12). The cyclic creep-rupture curve is used as the pure creep-rupture failure criterion. Failure is predicted to occur when the sum of the cycle and time ratios accumulates to unity.

When this procedure was first proposed, a few assumptions were made that had not as yet been adequately substantiated. Specifically, it was assumed that the strain-limited, cyclic creep-rupture curve used in creep-damage evaluation is independent of both the strain range and the compressive stress levels employed in the cyclic creep-rupture tests. Critical experiments have been conceived and results obtained that were used to check the validity of these assumptions. A rather complete series of cyclic creep-rupture tests were performed on two hardness levels of 316 stainless steel at $1300^{\circ} \mathrm{F}(980 \mathrm{~K})$. Limited test results were also obtained for the high-temperature titanium alloy $6 \mathrm{Al}-2 \mathrm{Sn}-$ $4 \mathrm{Zr}-2 \mathrm{Mo}$ at $900^{\circ}$ and $1100^{\circ} \mathrm{F}(755$ and $865 \mathrm{~K})$ and for the cobalt-base alloy L-605 at $1180^{\circ} \mathrm{F}(910 \mathrm{~K})$.

This report presents and discusses these cyclic creep-rupture results and their implications.

\section{BACKGROUND}

The need for a cyclic creep-rupture curve arose out of a study by Manson, Halford, and Spera of the role of creep in elevated-temperature, low-cycle fatigue testing conducted under strain-controlled conditions. It was recognized that some form of creeprupture failure criterion was required to explain the frequency and temperature dependence of strain-cycling failures experienced by specimens of L-605 and 316 stainless 
steel. Looking first to the conventional (constant load), monotonic, creep-rupture curve as a possible stress-time-dependent failure criterion, it was found that cyclic lives could be predicted correctly only from a qualitative standpoint. Computed lives in some cases were significantly lower than observed, indicating that such a failure criterion is too severe and at best can be used as a lower bound on life (refs. 5 and 6). This result, although not initially obvious, can be rationalized as follows: during a constant-load rupture test, the cross-sectional area decreases as the specimen creeps. The true stress experienced by the material in the test section therefore steadily increases as time progresses. Also, as the net strain in the specimen becomes larger, cavities and small cracks can open up, thus further reducing the load-carrying area. In addition to these impositions upon the material that tend to promote early failure, a necking instability may also set in, thus climaxing a truly severe test of a material's resistance to failure under creep stresses. The degree of severity would be expected to be the greatest for materials with high creep ductility.

A more realistic rupture test was therefore required that would assess a material's creep-rupture resistance during constrained cyclic loading, wherein these factors are not present. A cyclic creep-rupture test was proposed. In this test, alternate tensile and compressive loads are applied while the specimen creeps between fixed strain limits. This test satisfies the preceding requirements provided the test results are indeed stress-time dependent and are therefore independent of the magnitude of the strain range employed. Furthermore, any alterations in the metallurgical structure indigenous to reversed inelastic deformation would be reflected in a cyclic creep-rupture test, but not in a monotonic one.

\section{DETAILS OF EXPERIMENT}

\section{Specimens and Apparatus}

All the specimens tested in this program were machined from 0. 75-inch- (19-mm-) diameter bar stock. Three specimen configurations were employed. Tensile tests were conducted on solid, hourglass specimens of 0.25 -inch $(6.3-\mathrm{mm})$ diameter. Some of the monotonic creep-rupture tests were performed on specimens with a 0.25-inch- (6.3$\mathrm{mm}-)$ diameter and 1.5-inch- (38- $\mathrm{mm-})$ long cylindrical test section. The remainder of the monotonic creep-rupture tests and all the cyclic tests were conducted on tubular specimens with an hourglass test section. The specimens and details of the cycling apparatus are fully described in reference 13 and therefore are only briefly mentioned herein. For the cyclic tests, thermocouples were spot welded near the minimum test 
section and used to control the specimen temperature. Heat was supplied by an internally mounted, silicon carbide heating element. Cyclic strains were monitored by a diametral extensometer with a linear variable differential transformer (LVDT) sensor, and loads detected by an LVDT-instrumented proving ring that was loaded in series with the test specimen. Loads were applied by a closed-loop, servocontrolled hydraulic cylinder. Throughout the cyclic tests, temperature and load were closed-loop controlled, while the strain was limit controlled.

\section{Materials and Test Temperatures}

Two hardness levels of 316 stainless steel were tested at $1300^{\circ} \mathrm{F}(980 \mathrm{~K})$. The softer material ( $R_{B}=86$ to 87 ) is referred to as fully annealed, whereas the harder material $\left(R_{B}=95\right.$ to 96$)$ is termed partially annealed. A cobalt-base alloy, L-605, was tested at $1180^{\circ} \mathrm{F}(910 \mathrm{~K})$ in the unaged, solution-annealed condition. Tests were also performed at $900^{\circ}$ and $1100^{\circ} \mathrm{F}$ (755 and $865 \mathrm{~K}$ ) on a high-temperature, titanium-base alloy, 6Al-2Sn-4Zr-2Mo. This material was tested in the duplex-annealed condition achieved by the heat treatment schedule: $1675^{\circ} \mathrm{F}(1185 \mathrm{~K})$ for $1 / 2$ hour, air cooled; $1100^{\circ} \mathrm{F}(865 \mathrm{~K})$ for 8 hours, air cooled.

Short-time tensile properties and the coefficients in the universal slopes equation (ref. 11) are listed in table $I$ for the materials and test temperatures used. All tests were performed in a still-air environment.

\section{Test Procedure}

Cyclic creep-rupture tests were conducted in the manner shown schematically in figure 1. Once the desired test temperature had been reached, a tensile load (A) was applied and held constant while the specimen crept. The strain signal was continuously monitored. Upon reaching a preset tensile strain limit (B), the specimen was loaded in compression to an amount equal to the original tensile load (C). Generally a couple of seconds were spent in transferring the full load from one direction to the other. Once the full compressive load had been achieved, it was held constant while the specimen crept in compression back past zero strain (D) and finally to a preset compressive strain limit (E) equal in magnitude to the original tensile strain limit. Thereupon, the previous tensile load was reapplied $(F)$. This sequence was continuously repeated until the specimen ruptured into two pieces.

The cycling frequency was not programmed, but instead was dictated by the creep resistance of the material. For example, as the creep rates increased, the test fre- 
quency increased. The strain and load were generally recorded as functions of time. A schematic example of how these curves appeared is shown in the right-hand portion of figure 1. The elapsed total time and the time spent under the tensile stress were recorded, together with the number of cycles to failure.

The preceding test procedure was altered to allow for unequal tensile and compressive stresses by first introducing a mean load.

The specific test conditions are indicated as the results for each material are presented.

\section{Construction of Cyclic Creep-Rupture Curves}

The cyclic creep-rupture curves were constructed by plotting the tensile value of the cyclic creep stress against the "pure" tensile time-to-rupture for tests performed at several different tensile stress levels. The pure tensile time-to-rupture $t_{r}$ was calculated from the measured tensile time-to-rupture $t$ in accordance with the linear creep - fatigue-damage summation law (ref. 7):

$$
\frac{t}{t_{r}}+\frac{N}{N_{f}}=1
$$

where the cycle ratio $\mathrm{N} / \mathrm{N}_{\mathrm{f}}$ is the unavoidable fatigue damage that accrues by virtue of the application of $\mathrm{N}$ strain cycles. Manson's equation of universal slopes (ref. 11) was used to determine the "pure" fatigue life $N_{f}$ for an imposed total strain range $\Delta \epsilon$ :

$$
\Delta \epsilon=\frac{3.5 \sigma_{\mathrm{u}}}{\mathrm{E}}\left(\mathrm{N}_{\mathrm{f}}\right)^{-0.12}+\mathrm{D}^{0.6}\left(\mathrm{~N}_{\mathrm{f}}\right)^{-0.6}
$$

where $\sigma_{u}, E$, and $D$ are, respectively, the ultimate tensile strength, the modulus of elasticity, and the true fracture ductility as determined from the reduction of area. These properties were determined at the temperatures of interest from tensile tests at conventional strain rates.

The corrections made for fatigue damage in accordance with equation (1) did not significantly influence the positions of the cyclic creep-rupture curves shown in this report, since creep was the dominant damaging mechanism. However, this need not always be the case when other test conditions and materials are involved.

In calculating the pure tensile time-to-rupture according to equation (1), the magnitude of the compressive stress and its duration were ignored. Furthermore, the value 
of the strain range was assumed to be of importance only from the standpoint of permitting the calculation of the inherent fatigue damage. Justification of these actions forms the basis of this report.

\section{RESULTS AND DISCUSSION}

\section{Monotonic and Cyclic Creep-Rupture Curves}

The cyclic creep-rupture curve of a material can be significantly above and to the right of the corresponding conventional (constant load), monotonic creep-rupture curve, as indicated in figures $2(\mathrm{a})$ to $(\mathrm{d})$.

Titanium alloy 6Al-2Sn-4Zr-2Mo. - Figure 2(a) shows the monotonic and cyclic creep-rupture curves for the titanium alloy 6Al-2Sn-4Zr-2Mo. As shown in table II, all the cyclic tests on this material were conducted at a nominal total strain range of 4 percent.

The cyclic creep-rupture lives based on pure tensile time-to-rupture for a given tensile stress are about 10 times greater than the corresponding monotonic lives. Had the additional time spent under the compressive stress been retained when plotting the cyclic time-to-rupture, the difference between the monotonic and cyclic rupture times would be a factor of 20 . The additional factor of 2 arises since the tensile and compressive creep rates are approximately equal for this material and, hence, the times spent in compression and in tension are approximately equal. The large differences between the cyclic and monotonic rupture curves are attributed to the high monotonic creeprupture ductility (as indicated by the 60 to 90 percent reduction of area) of this material. This is consistent with the expectation that the severity of the monotonic test increases with increasing creep ductility, as was pointed out in the BACKGROUND section.

Cobalt-base alloy L-605. - Cyclic and monotonic creep-rupture results for the cobalt-base alloy L-605 are listed in table III and shown in figure 2(b). A 2-percent total strain range was employed except at the $70-\mathrm{ksi}\left(485-\mathrm{MN} / \mathrm{m}^{2}\right)$ stress level, where a 0.9 -percent range was used instead. Note the extremely low fatigue damage associated with these tests $\left(\mathrm{N} / \mathrm{N}_{\mathrm{f}}=0.003\right.$ to 0.025$)$. The differences in life between the conventional monotonic curve and the curve based on total cyclic time (tension plus compression) is also a factor of 20 for this material. However, the elapsed time spent under the tensile stress was only one-tenth the time spent under the equal compressive stress, because the compressive creep rates were only one-tenth the tensile creep rates. As a result, the cyclic (pure tensile time) and monotonic creep-rupture curves differ by only a factor of 2. This small difference should be expected considering the low creep ductility of this material. The creep ductility is low because of the significant strain-age hardening 
that occurs in the creep-rupture tests. For example, in the cyclic creep-rupture tests, it was necessary to harden the material to the high stress levels shown in figure 2 (b) by applying a few (two to five) strain cycles. Monotonic creep-rupture tests were subsequently performed on specimens subjected to this hardening procedure. A 10- to 14percent reduction of area was observed, which is significantly below the 47-percent reduction of area measured for this material in a conventional tensile test (table I).

Partially annealed 316 stainless steel. - A comparison of the cyclic and monotonic creep-rupture results for the partially annealed 316 stainless steel is shown in figure 2(c). As would be expected from the high monotonic creep-rupture ductility (approximately 75-percent reduction of area), there is a significantly large difference between the cyclic and conventional monotonic creep-rupture curves. Each plotted point represents the average time-to-rupture of all data available at the indicated stress (see table IV). Geometric mean values (arithmetic average of the logarithms) were used. As is pointed out in the section Effect of Strain Range, there is no significant difference between the results at the different strain ranges and, hence, the averaging process is justifiable. In the cyclic tests, the time spent in tension was found to be only about fourtenths the amount spent under compression.

Also shown in figure $2(\mathrm{c})$ are two test results obtained under constant true stress control. In these tests, diametral strain was monitored and used to compute the instantaneous cross-sectional area at the minimum test section. The creep load was then manually decreased with time to maintain an approximately constant true stress. Since these tests were conducted on tubular specimens, however, it was not possible to control the true stress beyond the point of tensile necking instability.

From these preliminary results, it appears that the monotonic (constant true stress), creep-rupture curve may be approximately coincident with the cyclic (pure tensile time), creep-rupture curve and could possibly be used in its place. Swindeman (ref. 14) arrived at a somewhat similar conclusion based on results with Inconel at $1500^{\circ} \mathrm{F}$ $(1090 \mathrm{~K})$. His results indicated that, "if constant stress, stress-rupture data are compared to low-cycle fatigue using the time under the tension stress, the data agree to within a factor of 2 on a time basis. "

If the cyclic and the true stress creep-rupture curves are identical, the implication is that the conventional, monotonic, creep-rupture curve is below the cyclic curve solely because the true stresses in the monotonic test are higher and not because of the accumulation of internal voids or cavities as net strain increases.

Fully annealed 316 stainless steel. - The most extensive rupture data were generated on the fully annealed 316 stainless steel. These are listed in table V. Figure 2(d) shows a comparison between the conventional monotonic and the cyclic creep-rupture curves. The difference in rupture time for a given stress is strikingly large (between a factor of 5 and 20). This would be expected for a material exhibiting high monotonic 
creep-rupture ductility (58- to 77-percent reduction of area). As is discussed in the following sections, several different strain ranges ( 0.8 to 4 percent) and levels of compressive stress ( 25 to $45 \mathrm{ksi} ; 170$ to $310 \mathrm{MN} / \mathrm{m}^{2}$ ) were employed in generating these cyclic rupture results. Each plotted point is based on the geometric mean of the pure tensile time-to-rupture of all tests conducted at a given tensile stress, and represents from four to nine individual tests. For the cyclic creep-rupture tests with completely reversed stresses, it was observed that the time spent under the tensile stress was only four-tenths the amount spent under the compressive stress. This result is identical with that found for the partially annealed 316 stainless steel discussed in the preceding section.

Before leaving the subject of comparison between the cyclic and the monotonic creeprupture curves, some additional comments regarding cyclic creep-rupture tests should be made.

For a given total strain range, there is a maximum stress above which a cyclic creep-rupture test cannot be conducted. This stress is equal to the flow stress which occurs at the selected total strain range. A cyclic test could only be run at a higher stress by selecting a larger total strain range. There are also, as discussed later in this section, practical limitations on the maximum strain range that should be used.

The cyclic creep-rupture curve should be expected to converge with the monotonic curve at short lives as the stress approaches the ultimate tensile strength.

There would appear to be an economic limitation to cyclic creep-rupture testing for long times, since relatively expensive testing facilities would usually be involved. However, a recent Russian paper (ref. 15) describes a simple mechanical system capable of performing cyclic creep-rupture tests in axial tension and compression. The author also constructed an inexpensive torsional cyclic creep-rupture machine a few years ago (ref. 16). Hence, cyclic creep-rupture testing need not be economically prohibitive.

\section{Effect of Strain Range}

For the cyclic creep-rupture curve to be of practical value, it must be a curve that expresses a unique relation between the cyclic creep stress and the time-to-rupture. The relation must therefore be independent of the cyclic strain range employed. Several series of tests were performed to check for this independence. In these tests, constant cyclic creep stresses were maintained (both tensile and compressive) while the strain range was varied from test to test. One such series is shown schematically in figure 3 . The 0.8-percent and 4-percent total strain ranges are considered to be practical extremes for the materials of this investigation. At smaller strain ranges, less of the total deformation is due to creep, and hence the exact deformation mechanism that should 
be featured is subordinated. The absolute minimum strain range is the elastic strain range, which of course leaves no room for inelastic strains of any sort. For total strain ranges much greater than 4 percent, the true stresses that develop near the strain limits begin to deviate from the nominal values by too great an extent. Larger strain ranges may also introduce other undesirable effects, such as roughening of the surface or even local buckling.

The effect of total strain range on the cyclic creep-rupture results is shown in figures 4(a) and (b) for the two hardness levels of 316 stainless steel. For the fully annealed material, there appears to be a slight increase in tensile rupture time with increasing strain range. However, the reverse is true for the partially annealed material at the highest and lowest stresses. No real significance is assigned to these differences in rupture time at the various strain ranges. These results are therefore taken to demonstrate the general lack of dependence of the cyclic creep-rupture curve on the imposed total strain range. This interpretation is also confirmed by limited data obtained for L-605. The cyclic creep-rupture results (tensile time) shown in figure 2(b) were generated at a strain range of 2 percent - with the exception of the $70-\mathrm{ksi}\left(485-\mathrm{MN} / \mathrm{m}^{2}\right)$ point, which was run at a strain range of only 0.9 percent. This latter point falls in line with the curve drawn through the remaining data points, thus further substantiating the independence of tensile rupture time with respect to strain range.

Since the cyclic creep-rupture curve is independent of the strain range, any convenient practical range can be selected. It is therefore recommended that the strain range be chosen large enough to permit the creep strains to be the dominant strains in the cycle, yet not so large that undesirable buckling or surface roughening occurs.

\section{Effect of Compressive Stress}

One of the potentially important variables in a cyclic creep-rupture test is the magnitude of the compressive stress employed. Since the cyclic creep-rupture curve relates only tensile stress to tensile time-to-rupture, it should be independent of the compressive stress. To check for an effect of compressive stress, several series of tests were conducted that were patterned after those shown schematically in figure 5 . If there is no effect of compressive stress, the tensile time-to-rupture should be constant for a specified tensile stress.

Results are presented in figure 6 for the fully annealed 316 stainless steel. Here the pure tensile rupture time is plotted against the cyclic compressive stress for four levels of tensile stress. The solid horizontal lines represent the geometric mean of all the tensile rupture times at the indicated tensile stresses. The results demonstrate a general lack of dependence on compressive stress. Although there are some deviations from 
the horizontal lines, these are assigned no real significance.

A particularly attractive consequence of this finding is the savings in testing time that can be realized by using high stresses in the compressive half of the cycle.

Although the compressive stress has a negligible effect on the pure tensile time-torupture, it was found to influence the tensile creep rates experienced at a given tensile stress. When the compressive stress was low, the tensile creep rate was high, and when the compressive stress was high, the tensile creep rate was low. An example of this behavior is presented in figure 7 for fully annealed 316 stainless steel. The average tensile creep rate (determined simply by dividing the total strain range of 4 percent by the tensile time of the cycle) for a tensile stress of $35 \mathrm{ksi}\left(240 \mathrm{MN} / \mathrm{m}^{2}\right)$ was evaluated on the 10th cycle for tests with different compressive stresses. As shown in figure 7, the tensile creep rate was a strong function of the compressive stress level employed.

A similar effect of tensile stress on compressive creep rate was not found, as is indicated by the nearly horizontal line drawn through the compressive creep rate data shown in figure 8 . The compressive stress was maintained at $35 \mathrm{ksi}\left(240 \mathrm{MN} / \mathrm{m}^{2}\right)$ and the tensile stress was varied from test to test. The average compressive creep rates were also evaluated on the 10th cycle.

As a direct consequence of having an approximately constant tensile time-to-rupture for a given tensile stress and yet a widely varying tensile creep rate depending on compressive stress level, the number of cycles to failure was also found to vary significantly. A careful examination of the cyclic life results in table $\mathrm{V}$ indicates that the cyclic life varies with compressive stress in a systematic manner. For a given total strain range and tensile stress, the cyclic life decreases as the compressive stress increases. Considering only the stresses and the number of cycles to failure, the conclusion might be drawn that not only is compressive stress damaging, but it is even more damaging than tensile stress. The fallacy of such an interpretation becomes apparent, however, when it is recognized that creep-rupture damage (time ratios) rather than fatigue damage (cycle ratios) was dominant in these tests. In the presence of high creep damage, the strain range and number of cycles to failure is of little or no value as an indicator of total damage. As shown in table $V$, for a strain range of 4 percent, cyclic lives varied from as low as 7 to as high as 130, depending systematically on the particular combination of tensile and compressive stresses. These and the other results in table $\mathrm{V}$ clearly demonstrate a lack of correlation between total strain range and cycles to failure, and hence further reinforce the contention that these results are indeed predominantly stresstime dependent. 


\section{Accelerated Creep}

During the cyclic creep-rupture tests, both the tensile and compressive creep rates of all the materials investigated steadily increased after the first few applied cycles. This is in spite of the fact that one of the materials, for example, was in the fully annealed condition and might have been expected to harden as a result of cyclic loading. Evidence of cyclic increases in creep rates was first observed in torsion and reported by Morrow and Halford (ref. 16). The phenomenon has been termed "creep acceleration due to repeated stress reversals." Kitagawa (ref. 17) has more recently documented a grain boundary rotation mechanism that is believed to be responsible for creep acceleration in lead at room temperature.

Figures 9 and 10 are plots of some typical results showing the acceleration of the average tensile creep rates with applied cycles for the fully annealed 316 stainless steel. At the highest stresses, the creep rates increased the most during the test. As shown in figure 9 , the average tensile creep rates for $\pm 40 \mathrm{ksi}\left(275 \mathrm{MN} / \mathrm{m}^{2}\right)$ increased by more than a factor of 30 from start to finish; whereas, for the $\pm 25-\mathrm{ksi}\left(170-\mathrm{MN} / \mathrm{m}^{2}\right) \mathrm{stress}$, the increase was a more modest factor of 3 . It was observed that when the tensile and compressive stresses were completely reversed, the creep acceleration was greatest. One such example is shown in figure 9 , where comparison can be made between the curves for $\pm 25 \mathrm{ksi}\left(170 \mathrm{MN} / \mathrm{m}^{2}\right)$ and for $+25 /-40 \mathrm{ksi}\left(+170 /-275 \mathrm{MN} / \mathrm{m}^{2}\right)$.

\section{Tensile and Compressive Creep Rates}

This program has permitted a comparison of creep rates under conditions of equal tensile and compressive stresses. One of the more significant findings is that the difference in tensile and compressive creep rates is strongly material dependent. It was found that the ratio of the average compressive-to-tensile creep rates for $L-605$ is about 0.1 ; but for the titanium alloy, the ratio is 1.0 . Figure 10 shows some results for the partially annealed 316 stainless steel. The creep rates in this case were measured at zero diametral strain (corresponding to points such as $D$ and $G$ in fig. 1) and, hence, at a point where the true stresses are exactly equal for equal tensile and compressive loads. A large strain range of 9 percent was used in this case to ensure that the creep rates reached in passing through the zero strain point were approaching steadystate creep conditions. The ratio of compressive-to-tensile creep rates was approximately constant at a value of about 0.4 throughout the entire test. This is consistent with an average value of 0.4 for the ratio of the time spent under tensile stress to the time spent under compressive stress for all the other completely reversed stress, cyclic creep-rupture tests performed on both the partially and fully annealed 316 stainless steels. 


\section{SUMMARY OF RESULTS}

In a paper by S. Manson, G. Halford, and D. Spera to be published in the A. E. Johnson Memorial Volume (A. S. Smith, ed.; Elsevier Publishing Company Ltd.), a new material characteristic called the cyclic creep-rupture curve was proposed as a valuable aid in the analysis and prediction of high-temperature, strain-cycling life. A cyclic creep-rupture curve was generated by plotting the tensile stress as a function of the pure tensile time-to-rupture obtained from a completely reversed cyclic creeprupture test. Limited data available at the time suggested that the cyclic creep-rupture curve might be independent of the magnitude of the range of strain and the compressive creep stress level employed. An experimental program was therefore initiated and specifically directed toward answering the question of its dependence, or lack thereof, on these two variables. Tests were conducted with the titanium alloy $6 \mathrm{Al}-2 \mathrm{Sn}-4 \mathrm{Zr}-2 \mathrm{Mo}$ at $900^{\circ}$ and $1100^{\circ} \mathrm{F}(755$ and $865 \mathrm{~K})$, with the cobalt-base alloy L-605 at $1180^{\circ} \mathrm{F}(910 \mathrm{~K})$, and with 316 stainless steel at $1300^{\circ} \mathrm{F}(980 \mathrm{~K})$ for two hardness levels.

The following major results were obtained:

1. The cyclic creep-rupture curves lie above and to the right of the conventional (constant load), monotonic curves by factors ranging from 2 to 20 in rupture time. This factor is large when the monotonic creep-rupture ductility is large.

2. The pure tensile time-to-rupture for a given tensile stress was approximately constant and independent of the practical ranges of strain considered.

3. The pure tensile time-to-rupture for a given tensile stress was found to be approximately independent of the compressive stress employed in the cyclic creeprupture tests.

4. The creep rates in tension for a given tensile stress were highest when the com-

pressive stress was lowest. However, the creep rates in compression for a given compressive stress were independent of the tensile stress level.

5. For an imposed total strain range, the number of cycles to failure could be varied significantly depending on the selected combination of tensile and compressive stresses.

6. During all the cyclic creep-rupture tests, the creep rates in both tension and compression increased with applied cycles. This behavior was most pronounced when the cyclic creep stresses were high and when the tensile and compressive stresses were completely reversed.

7. Compressive creep rates were generally lower than the tensile creep rates, but the differences depended on the material. For L-605, the ratio of compressive creep 
rate to tensile creep rate was approximately 0.1 . The same ratio for the stainless steels was approximately 0.4; and for the titanium alloy the creep rates were nearly equal, resulting in a ratio of 1.0 .

Lewis Research Center,

National Aeronautics and Space Administration, Cleveland, Ohio, January 7, 1971, 129-03.

\section{REFERENCES}

1. Manson, S. S.: Interfaces Between Fatigue, Creep, and Fracture. Int. J. Fracture Mech., vol. 2, no. 1, Mar. 1966, pp. 327-363.

2. Manson, S. S. ; and Halford, G. R.: A Method of Estimating High-Temperature LowCycle Fatigue Behavior of Materials. Proceedings of the International Conference on Thermal and High-Strain Fatigue. The Metals and Metallurgy Trust, London, 1967, pp. 154-170.

3. Halford, G. R. ; and Manson, S. S. : Application of a Method of Estimating HighTemperature Low-Cycle Fatigue Behavior of Materials. Trans. ASM, vol. 61, no. 1, Mar. 1968, pp. 94-102.

4. Conn, Andrew F.; and Thiruvengadam, A.: Experimental Research on High Frequency Fatigue and Dynamic Tensile Tests at Elevated Temperatures. Rep. TR829-1, Hydronautics, Inc. (NASA CR-72618), July 1969.

5. Spera, David A. : The Calculation of Elevated-Temperature Cyclic Life Considering Low-Cycle Fatigue and Creep. NASA TN D-5317, 1969.

6. Spera, David A.: Calculation of Thermal-Fatigue Life Based on Accumulated Creep Damage. NASA TN D-5489, 1969.

7. Taira, Shuji: Lifetime of Structures Subjected to Varying Load and Temperature. Creep in Structures. Nicholas J. Hoff, ed., Academic Press, 1962, pp. 96-124.

8. Palmgren, Arvid: Die Lebensdauer von Kugellagern. Ver. Deut. Ing. Zeit, vol. 68, no. 14, Apr. 5, 1924, pp. 339-341.

9. Langer, B. F.: Fatigue Failure From Stress Cycles of Varying Amplitude. J. Appl. Mech., vol. 4, no. 4, Dec. 1937, pp. A-160 to A-162.

10. Miner, M. A. : Cumulative Damage in Fatigue. J. Appl. Mech., vol. 12, no. 3, Sept. 1945, pp. A-159 to A-164. 
11. Manson, S. S.: Fatigue: A Complex Subject -Some Simple Approximations. Exp. Mech., vol. 5, no. 7, July 1965, pp. 193-226.

12. Robinson, Ernest L.: Effect of Temperature Variation on the Long-Time Rupture Strength of Steels. Trans. ASME, vol. 74, no. 5, July 1952, pp. 777-781.

13. Hirschberg, M. H.: A Low Cycle Fatigue Testing Facility. Manual on Low Cycle Fatigue Testing. Spec. Tech. Publ. No. 465, ASTM, 1969, pp. 67-86.

14. Swindeman, R. W.: The Interrelation of Cyclic and Monotonic Creep Rupture. Proceedings of the Joint International Conference on Creep. Inst. Mech. Eng. , London, 1963, pp. 3-71 to 3-76.

15. Getsov, L. B. : Investigation into High-Temperature Creep in Cyclic Tension and Compression. Industrial Lab., vol. 34, no. 11, Nov. 1968, pp. 1656-1657.

16. Morrow, Jo Dean; and Halford, G. R. : Creep Under Repeated Stress Reversals. Proceedings of the Joint International Conference on Creep. Inst. Mech. Eng. , London, 1963, pp. 3-43 to 3-47.

17. Kitagawa, Masaki: Enhanced Grain Boundary Sliding During Reversed Creep of Lead. T\&AM Rep. No. 319, Univ. Illinois (NASA CR-100316), Oct. 1968. 
TABLE I. - ELEVATED-TEMPERATURE, SHORT-TERM, TENSILE PROPERTIES

\begin{tabular}{|c|c|c|c|c|c|c|c|c|c|c|c|}
\hline \multirow{5}{*}{ Material } & \multirow{2}{*}{\multicolumn{2}{|c|}{ Temperature }} & \multirow{3}{*}{\multicolumn{2}{|c|}{$\begin{array}{l}\text { Elastic modulus, } \\
\mathrm{E}\end{array}$}} & \multirow{5}{*}{$\begin{array}{l}\text { Poisson's } \\
\text { ratio }\end{array}$} & \multirow{4}{*}{\multicolumn{2}{|c|}{$\begin{array}{c}\text { Ultimate } \\
\text { tensile } \\
\text { strength, } \\
\sigma_{\mathrm{u}}\end{array}$}} & \multirow{5}{*}{$\begin{array}{c}\text { Reduction } \\
\text { of area, } \\
\text { percent }\end{array}$} & \multirow{5}{*}{$\begin{array}{c}\text { True } \\
\text { ductility, } \\
\text { D }\end{array}$} & \multirow{2}{*}{\multicolumn{2}{|c|}{ Coefficients }} \\
\hline & & & & & & & & & & & \\
\hline & \multirow{3}{*}{${ }^{o} \mathrm{~F}$} & \multirow{3}{*}{$\mathrm{K}$} & & & & & & & & \multirow{3}{*}{$D^{0.6}$} & \multirow{3}{*}{$3.5 \sigma_{u} / E$} \\
\hline & & & \multirow[t]{2}{*}{ ksi } & \multirow[t]{2}{*}{$\mathrm{MN} / \mathrm{m}^{2}$} & & & & & & & \\
\hline & & & & & & ksi & $\mathrm{MN} / \mathrm{m}^{2}$ & & & & \\
\hline Titanium alloy & 900 & 755 & $12.7 \times 10^{3}$ & $87.5 \times 10^{3}$ & 0.32 & 110.0 & 760 & 57 & 0.85 & 0.91 & 0.030 \\
\hline $6 \mathrm{Al}-2 \mathrm{Sn}-4 \mathrm{Z} \mathrm{r}-2 \mathrm{Mo}$ & 1100 & 865 & 10.4 & 72 & .32 & 94.0 & 650 & 59 & .90 & .94 & .032 \\
\hline $\begin{array}{l}\text { Cobalt-base alloy } \\
\text { L-605 }\end{array}$ & 1180 & 910 & $25.0 \times 10^{3}$ & $170 \times 10^{3}$ & 0.27 & 96.5 & 665 & 47 & 0.64 & 0.77 & 0.014 \\
\hline $\begin{array}{l}316 \text { Stainless steel: } \\
\text { Fully annealed }\end{array}$ & 1300 & 980 & $20.5 \times 10^{3}$ & $140 \times 10^{3}$ & 0.30 & 45.5 & 315 & 54 & 0.77 & 0.85 & 0.0078 \\
\hline Partially annealed & 1300 & 980 & 20.5 & 140 & .30 & 56.5 & 390 & 64 & 1.02 & 1.14 & .0097 \\
\hline
\end{tabular}

TABLE II. - MONOTONIC AND CYCLIC CREEP-RUPTURE RESULTS FOR

TITANIUM ALLOY 6Al-2Sn-4Zr-2Mo

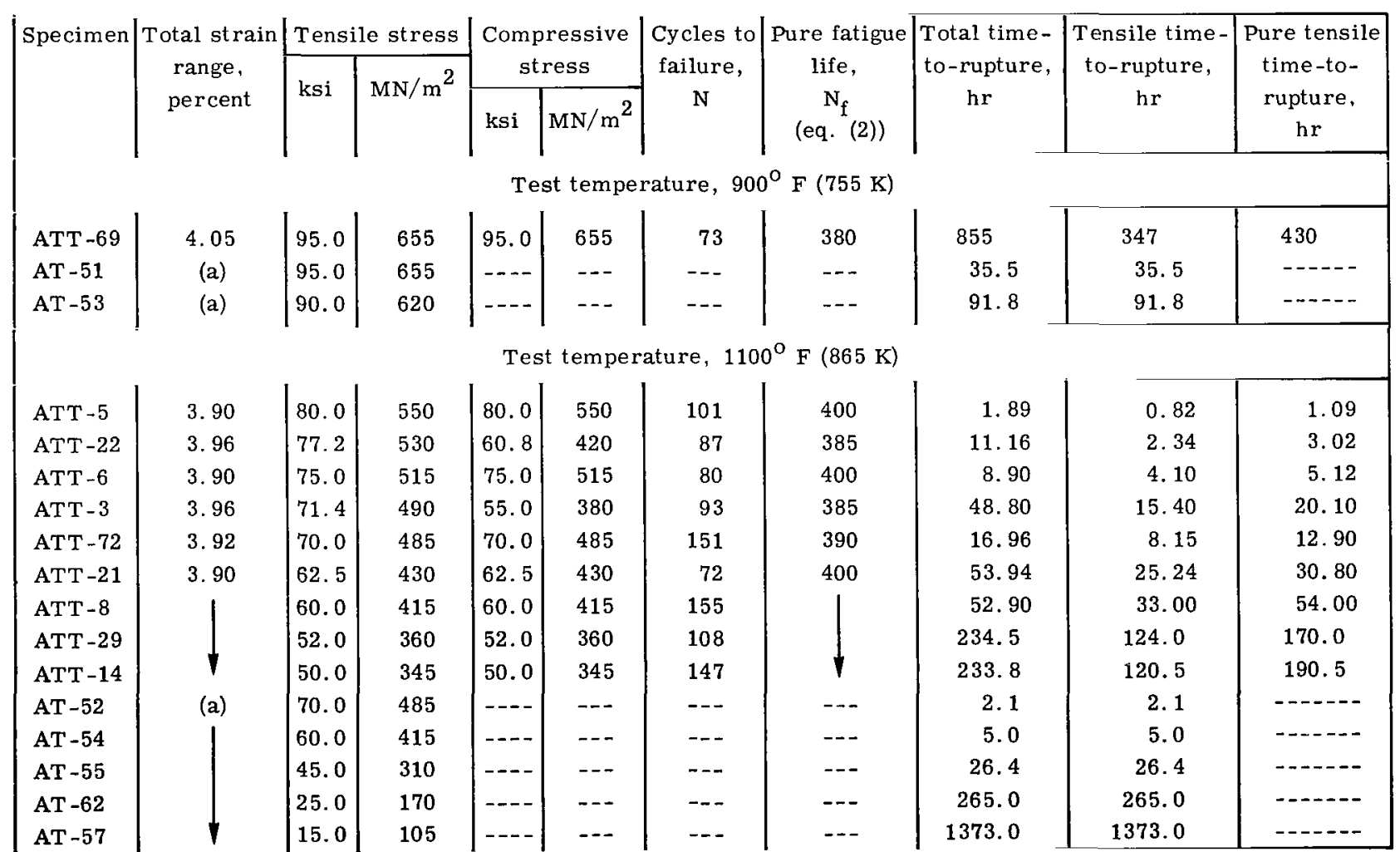

a Monotonic; constant load. 
TABLE III. - MONOTONIC AND CYCLIC CREEP-RUPTURE RESULTS FOR

COBALT-BASE ALLOY L-605 AT $1180^{\circ} \mathrm{F}$ (910 K)

\begin{tabular}{|c|c|c|c|c|c|c|c|c|c|c|}
\hline \multirow[t]{3}{*}{ Specimen } & \multirow{3}{*}{$\begin{array}{c}\text { Total strain } \\
\text { range, } \\
\text { percent }\end{array}$} & \multicolumn{2}{|c|}{ Tensile stress } & \multirow{2}{*}{\multicolumn{2}{|c|}{$\begin{array}{l}\text { Compressive } \\
\text { stress }\end{array}$}} & \multirow{3}{*}{$\begin{array}{c}\text { Cycles to } \\
\text { failure, } \\
\mathbf{N}\end{array}$} & \multirow{3}{*}{$\left|\begin{array}{c}\text { Pure fatigue } \\
\text { life, } \\
\mathrm{N}_{\mathrm{f}} \\
\text { (eq. (2)) }\end{array}\right|$} & \multirow{3}{*}{$\begin{array}{c}\text { Total time- } \\
\text { to-rupture, } \\
\text { hr }\end{array}$} & \multirow{3}{*}{$\begin{array}{c}\text { Tensile time- } \\
\text { to-rupture, } \\
\text { hr }\end{array}$} & \multirow{3}{*}{$\begin{array}{l}\text { Pure tensile } \\
\text { time-to- } \\
\text { rupture, } \\
\text { hr }\end{array}$} \\
\hline & & \multirow{2}{*}{$\mathrm{ksi}$} & \multirow{2}{*}{$\mathrm{MN} / \mathrm{m}^{2}$} & & & & & & & \\
\hline & & & & $\mathrm{ksi}$ & $\mathrm{MN} / \mathrm{m}^{2}$ & & & & & \\
\hline $\mathrm{ZZ}-75$ & 2.00 & 83.7 & 575 & 83.7 & 575 & $20 \frac{1}{2}$ & 810 & 1.87 & 0.194 & 0.199 \\
\hline $\mathrm{zZ}-60$ & 2.04 & 77.3 & 535 & 72.2 & 500 & 12 & 780 & 2.34 & .635 & .645 \\
\hline $\mathrm{zZ}-92$ & 2.00 & 75.0 & 515 & 75.0 & 515 & $9 \frac{1}{2}$ & 810 & 29.5 & 1.67 & 1.69 \\
\hline $\mathrm{ZZ}-73$ & .90 & 70.0 & 485 & 70.0 & 485 & 17. & 5800 & 42.0 & 4. 34 & 4.35 \\
\hline $\mathrm{ZZ}-74$ & 2.00 & 65.0 & 450 & 65.0 & 450 & $2 \frac{1}{2}$ & 810 & 196.0 & 15.2 & 15.3 \\
\hline $\mathrm{ZN}-12$ & (a) & 75.0 & 515 & --- & - & --- & ---- & 1.4 & 1.4 & ----- \\
\hline $\mathrm{ZN}-11$ & 1 & 70.0 & 485 & --- & -- & $-\cdots$ & $-\cdots$ & 1.7 & 1.7 & ----- \\
\hline $\mathrm{ZN}-13$ & & 65.0 & 450 & --- & --- & -- & $\ldots--$ & 9.6 & 9.6 & $-\ldots--$ \\
\hline $\mathrm{ZN}-15$ & 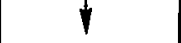 & 60.0 & 415 & $-\ldots$ & -- & $\ldots$ & -.-- & 10.8 & 10.8 & $-\cdots---$ \\
\hline
\end{tabular}

a Monotonic; constant load.

TABLE IV. - MONOTONIC AND CYCLIC CREEP-RUPTURE RESULTS FOR PARTIALLY ANNEALED 316 STAINLESS STEEL AT $1300^{\circ} \mathrm{F}(980 \mathrm{~K})$

\begin{tabular}{|c|c|c|c|c|c|c|c|c|c|c|}
\hline \multirow[t]{3}{*}{ Specimen } & \multirow{3}{*}{$\begin{array}{c}\text { Total strain } \\
\text { range, } \\
\text { percent }\end{array}$} & \multicolumn{2}{|c|}{ Tensile stress } & \multirow{2}{*}{\multicolumn{2}{|c|}{$\begin{array}{c}\text { Compressive } \\
\text { stress }\end{array}$}} & \multirow{3}{*}{$\begin{array}{c}\text { Cycles to } \\
\text { failure, } \\
\mathrm{N}\end{array}$} & \multirow{3}{*}{$\begin{array}{c}\text { Pure fatigue } \\
\text { life } \\
\mathrm{N}_{\mathrm{f}} \\
\text { (eq. }(2))\end{array}$} & \multirow{3}{*}{$\begin{array}{c}\text { Total time- } \\
\text { to-rupture, } \\
\text { hr }\end{array}$} & \multirow{3}{*}{$\begin{array}{c}\text { Tensile time- } \\
\text { to-rupture, } \\
\text { hr }\end{array}$} & \multirow{3}{*}{$\begin{array}{l}\text { Pure tensile } \\
\text { time-to- } \\
\text { rupture, } \\
\text { hr }\end{array}$} \\
\hline & & \multirow{2}{*}{$\mathrm{ksi}$} & \multirow{2}{*}{$\mathrm{MN} / \mathrm{m}^{2}$} & & & & & & & \\
\hline & & & & $\mathrm{ksi}$ & $\mathrm{MN} / \mathrm{m}^{2}$ & & & & & \\
\hline$Y Y-111$ & 4.09 & 50.0 & 345 & 50.0 & 345 & 33 & 270 & 0.230 & 0.115 & 0.132 \\
\hline $\mathrm{YY}-110$ & 1.94 & 50.0 & 345 & 50.0 & 345 & 118 & 1150 & .366 & .183 & .205 \\
\hline$Y Y-51$ & 4.09 & 45.0 & 310 & 45.0 & 310 & 52 & 270 & 6.00 & 1.71 & 2.13 \\
\hline YY-135 & 1.95 & 45.0 & 310 & 45.0 & 310 & 120 & 1150 & 11.33 & 1.53 & 1. 72 \\
\hline YY -138 & 4.05 & 40.0 & 275 & 30.0 & 205 & 85 & 275 & 134.4 & 5.79 & 8. 37 \\
\hline$Y Y-136$ & 4.09 & 40.0 & 275 & 40.0 & 275 & 30 & 270 & 13.6 & 6.17 & 6.95 \\
\hline$Y Y-133$ & 1.95 & 40.0 & 275 & 40.0 & 275 & 113 & 1150 & 30.0 & 10.17 & 11.25 \\
\hline$Y Y-141$ & 4.05 & 32.5 & 225 & 32.5 & 225 & 90 & 275 & 215.8 & 60.6 & 90.2 \\
\hline YY -27 & (a) & 40.0 & 275 & $\ldots$ & -- & -- & --- & 1.00 & 1.00 & -....- \\
\hline$Y Y-28$ & (a) & 40.0 & 275 & --- & --- & -- & $\ldots$ & 3.33 & 3.33 & ----- \\
\hline$Y Y-36$ & (a) & 32.0 & 220 & ---- & --- & -- & --- & 11.6 & 11.6 & ----- \\
\hline$Y Y-26$ & (b) & 49.3 & 340 & -- & --- & --- & --- & .453 & .453 & $-\cdots-$ \\
\hline $\mathrm{YY}-32$ & (b) & 40.0 & 275 & $-\cdots$ & -- & $-m-$ &.-- & 4.68 & 4.68 & ----- \\
\hline
\end{tabular}

a Monotonic; constant load.

$\mathrm{b}_{\text {Monotonic; constant true stress. }}$ 
TABLE V. - MONOTONIC AND CYCLIC CREEP-RUPTURE RESULTS FOR FULLY ANNEALED 316 STAINLESS STEEL AT $1300^{\circ} \mathrm{F}$ (980 K)

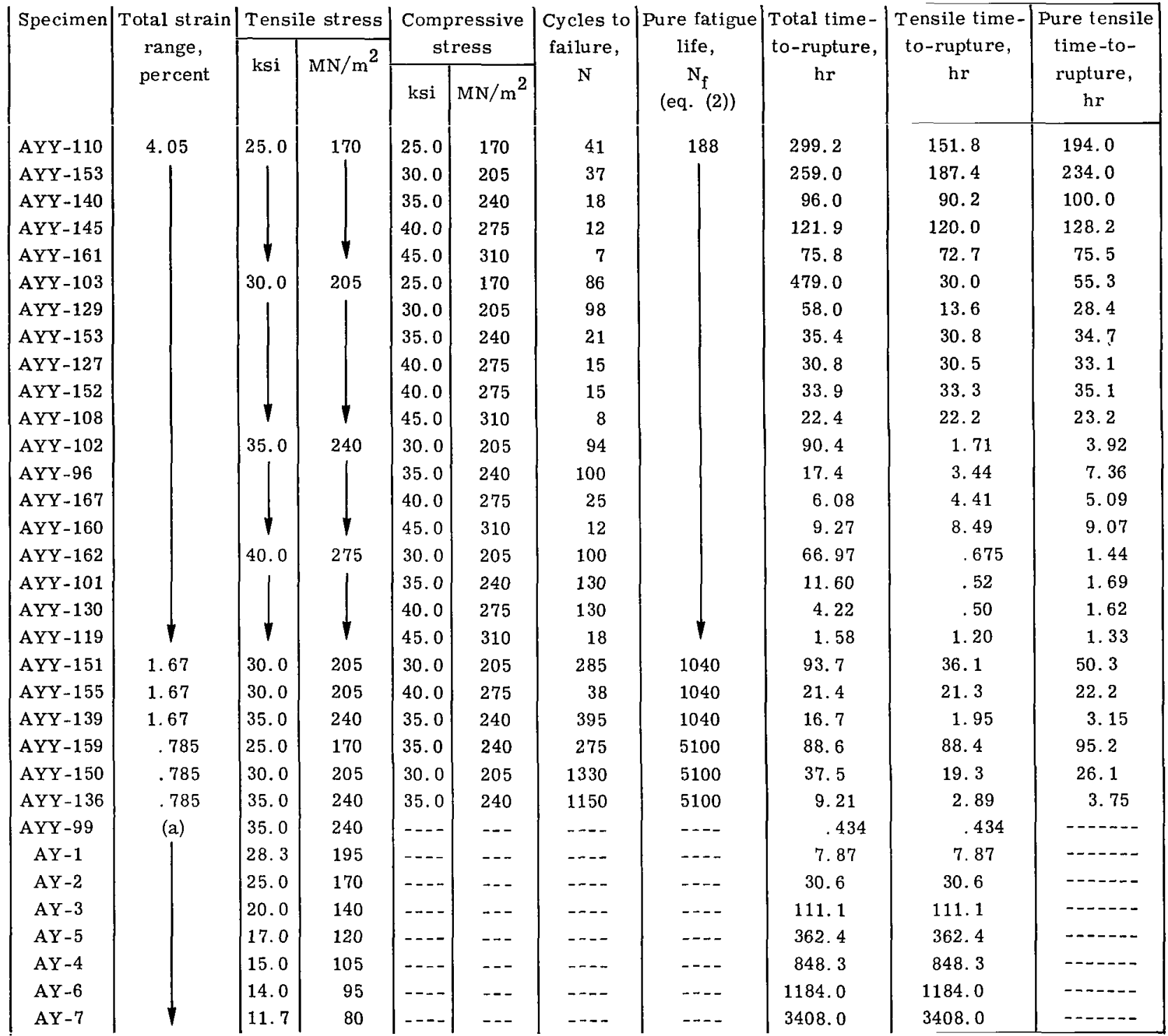

Monotonic; constant load. 

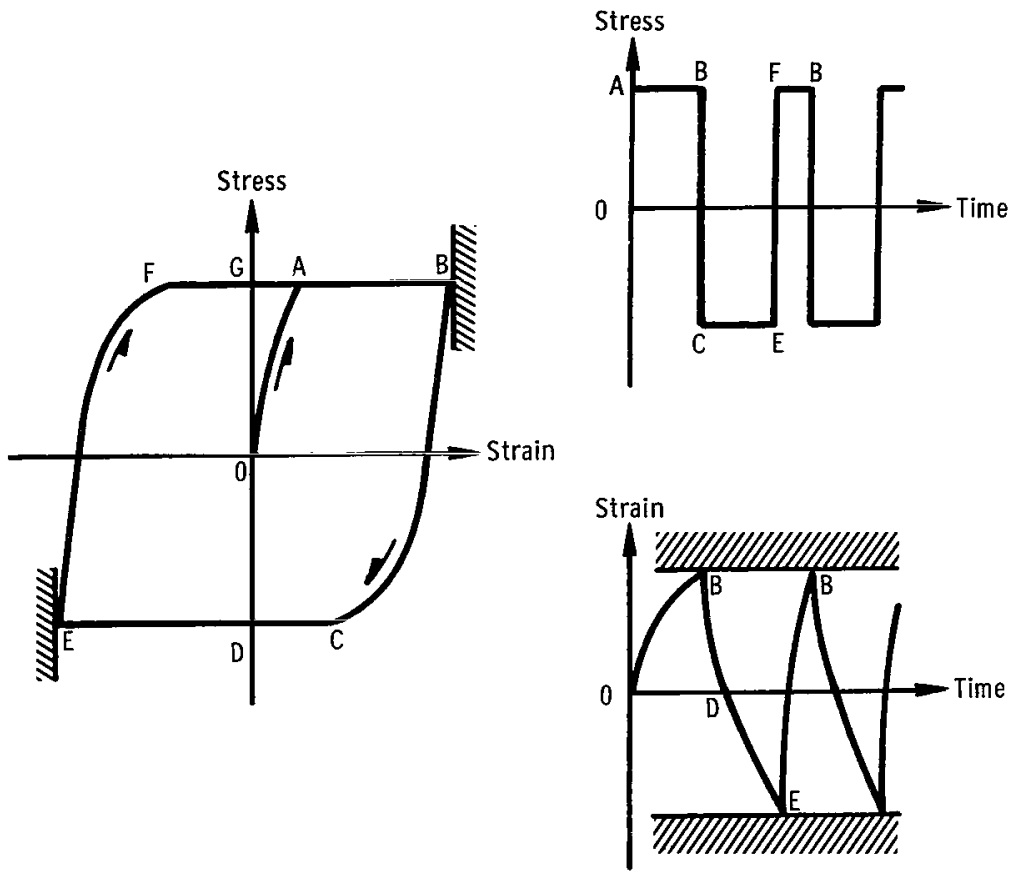

Figure 1 - Cyclic creep-rupture test. 


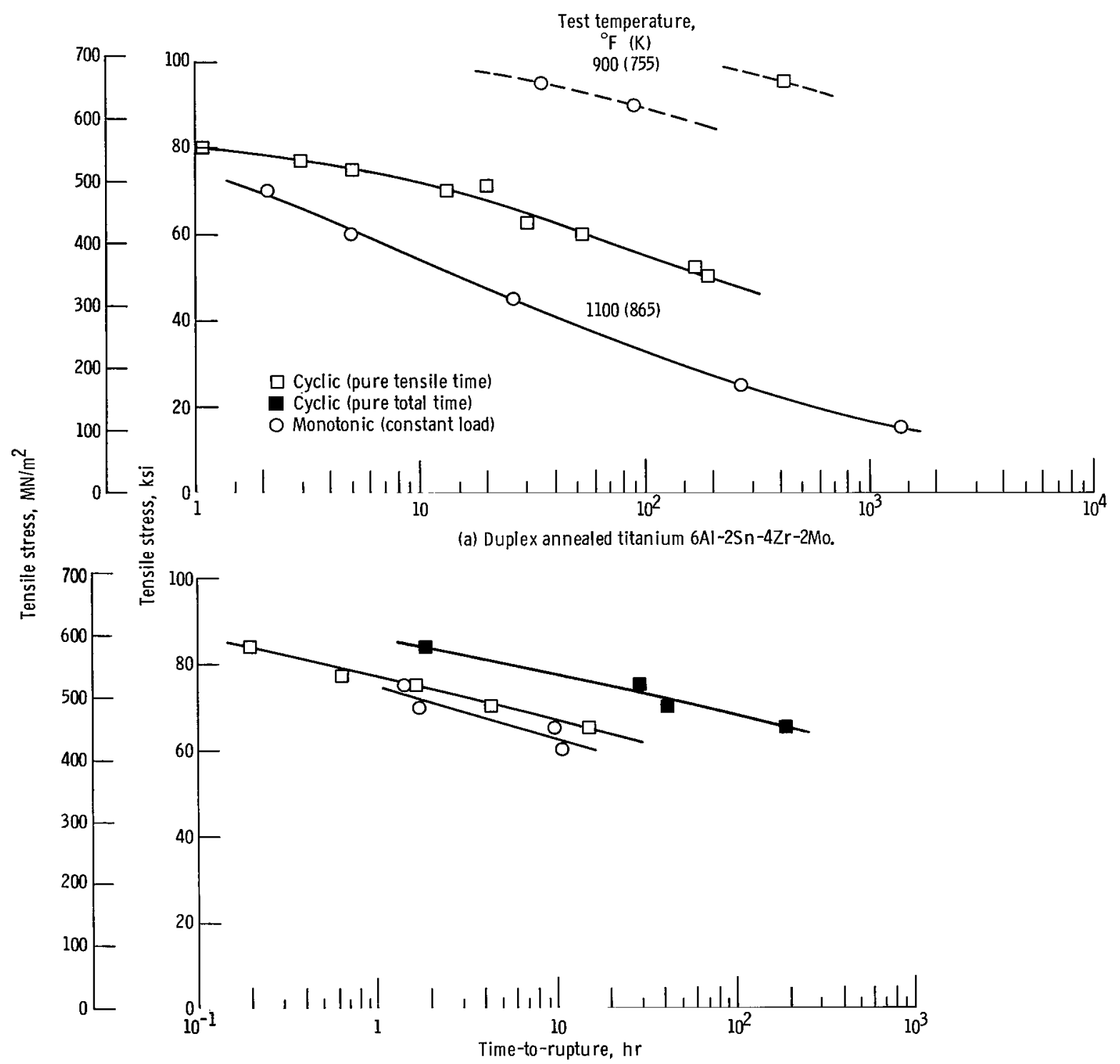

(b) Cobalt-base alloy L-605; test temperature, $1180^{\circ} \mathrm{F}(910 \mathrm{~K})$.

Figure 2. - Creep-rupture curves. 


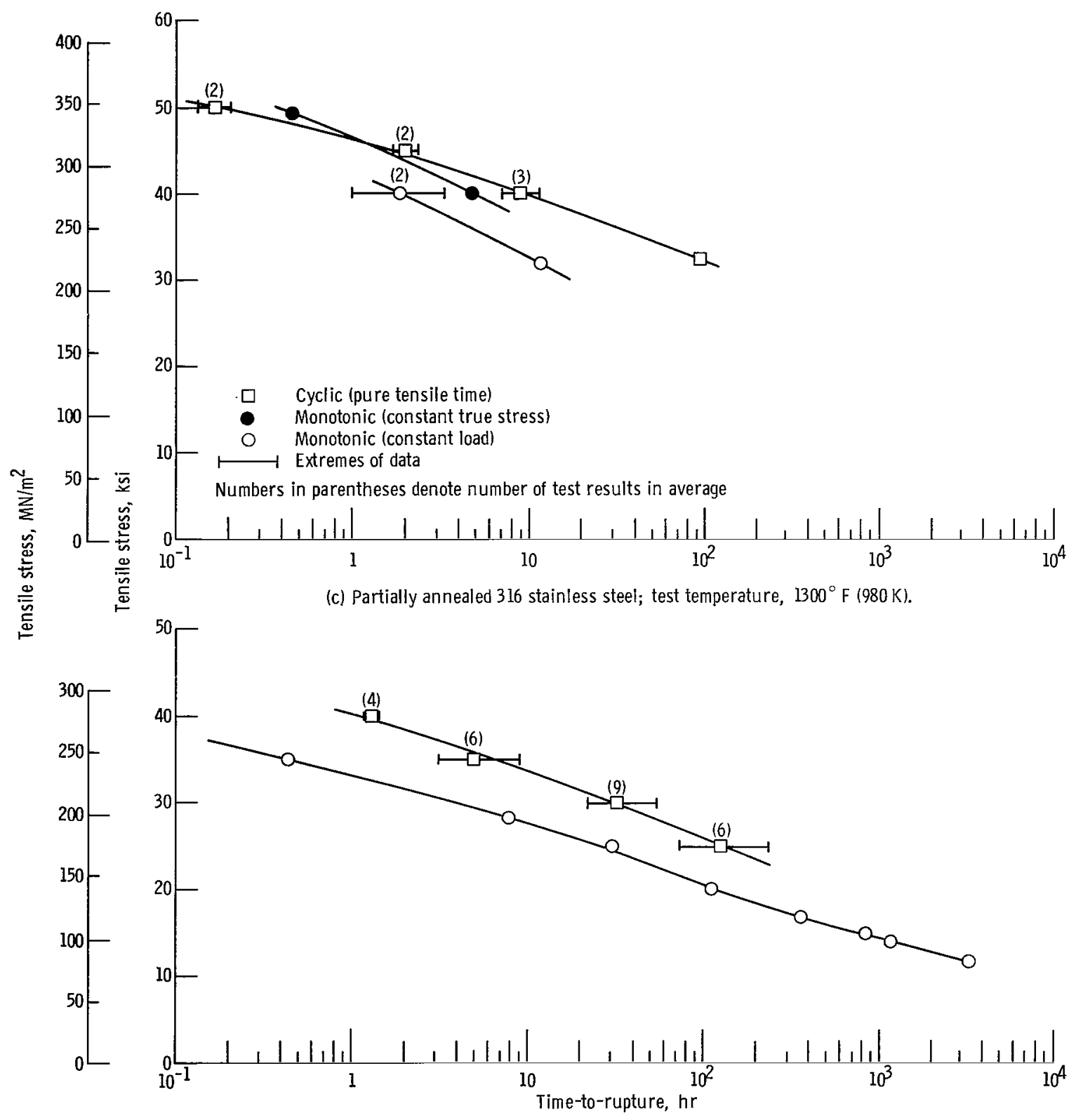

(d) Fully annealed 316 stainless steel; test temperature, $1300^{\circ} \mathrm{F}(980 \mathrm{~K})$.

Figure 2. - Concluded. 


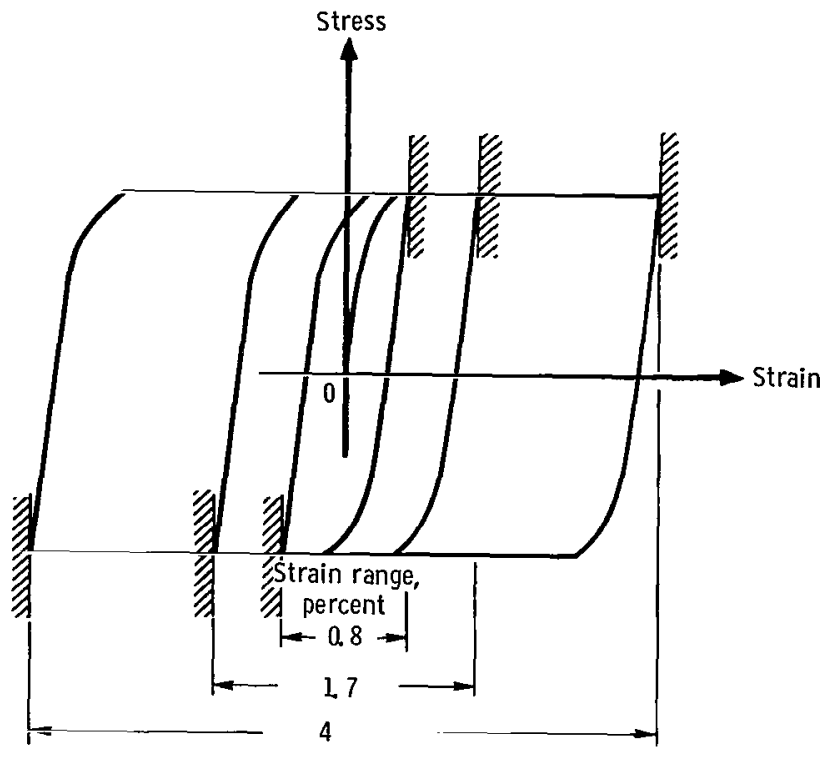

Figure 3. - Cyclic creep-rupture tests at various strain ranges.

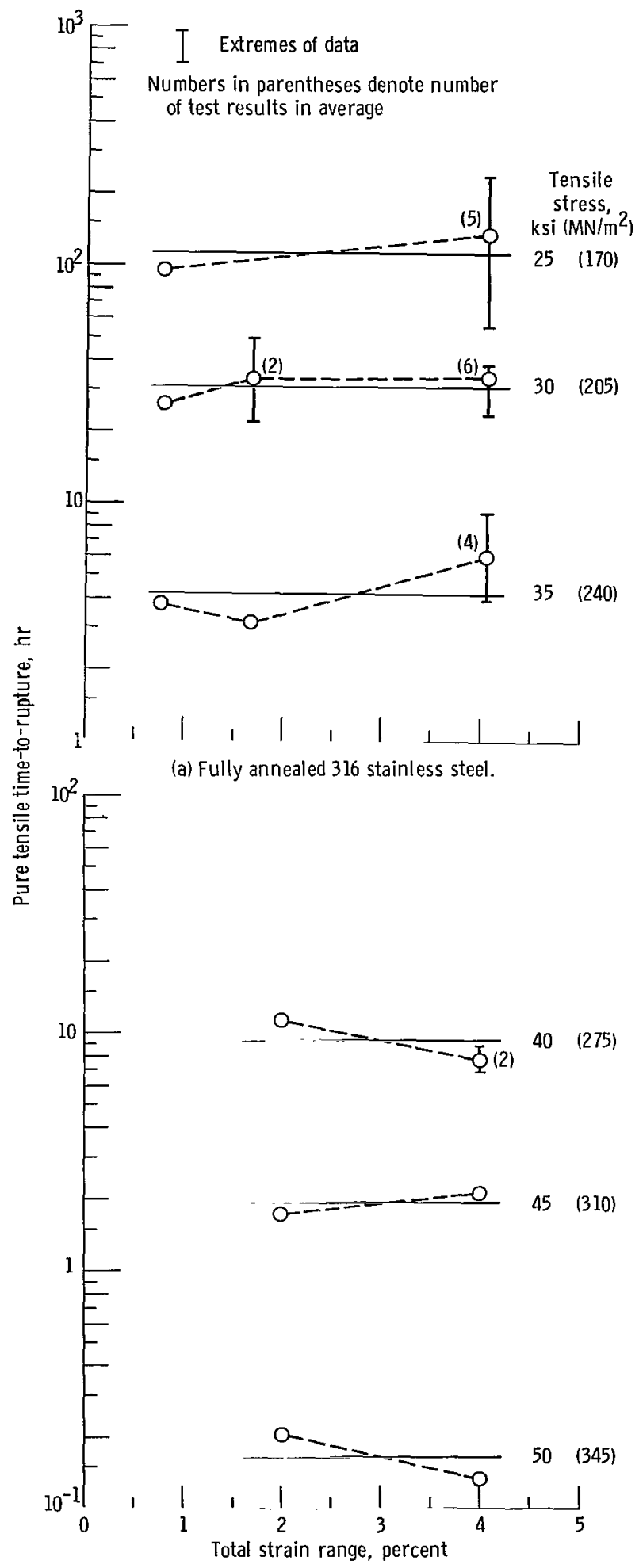

(b) Partially annealed 316 stainless steel.

Figure 4. - Approximate independence of pure tensile timeto-rupture relative to total strain range. Test temperature, $1300^{\circ} \mathrm{F}(980 \mathrm{~K})$. 


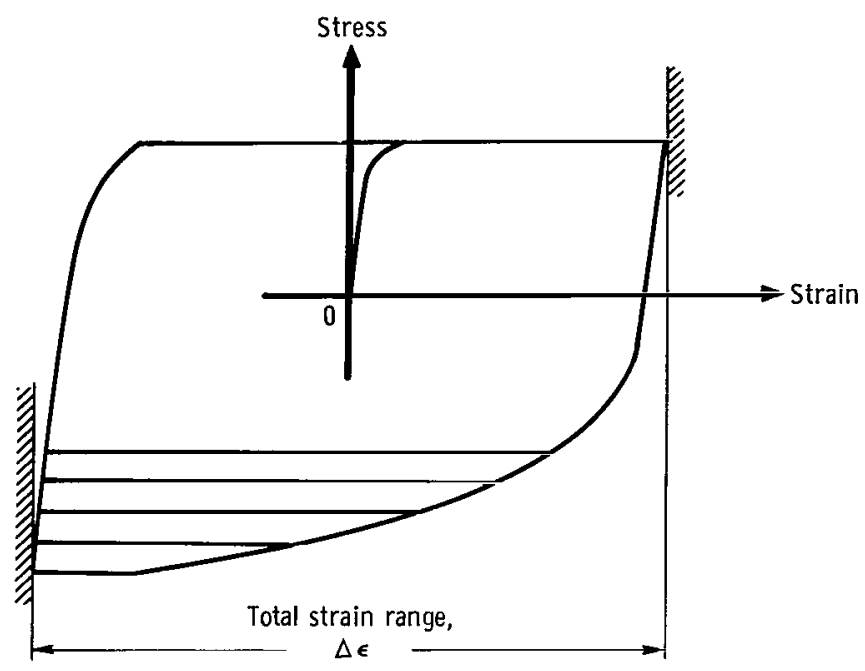

Figure 5. - Cyclic creep-rupture tests with different compressive stresses.

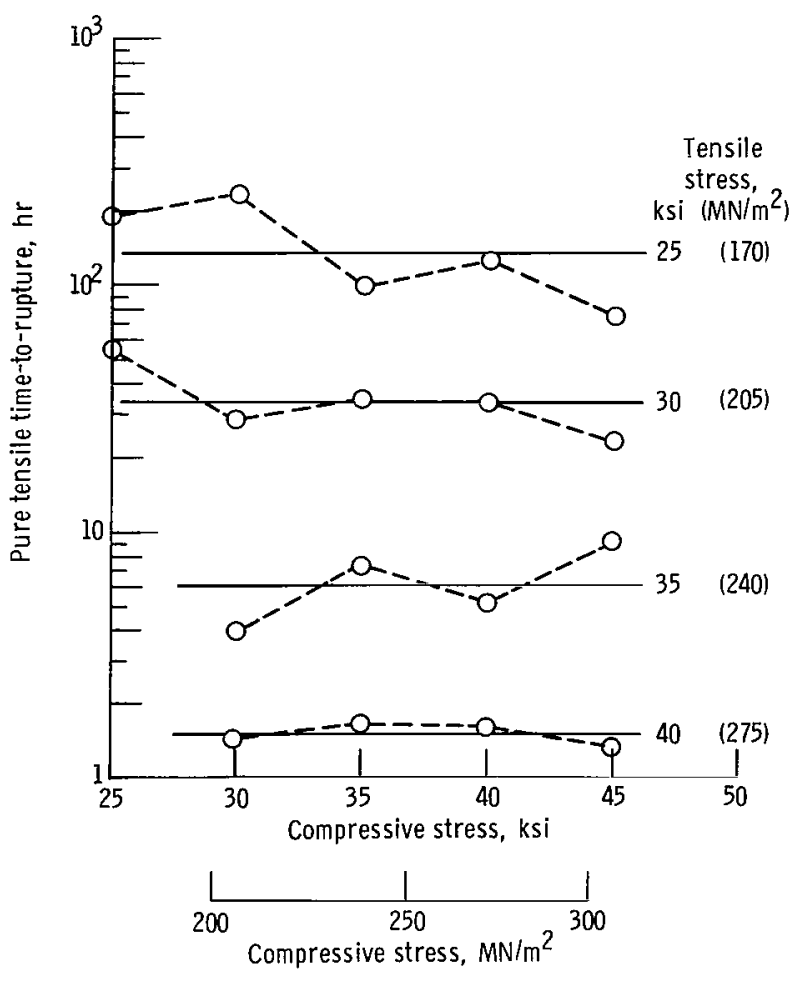

Figure 6. - Approximate independence of pure tensile time-torupture with respect to compressive stress for fully annealed 316 stainless steel. Test temperature, $1300^{\circ} \mathrm{F}(980 \mathrm{~K})$; total strain range, 4 percent. 


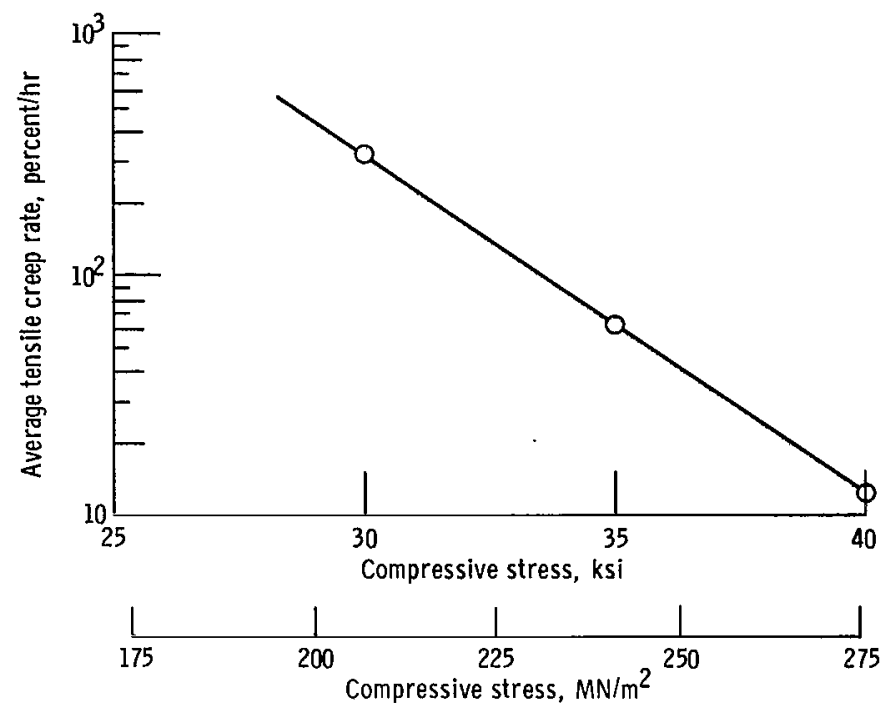

Figure 7. - Effect of compressive stress on tensile creep rate at tensile stress of $35 \mathrm{ksi}\left(240 \mathrm{MN} / \mathrm{m}^{2}\right)$ for fully annealed 316 stainless steel. Test temperature, $1300^{\circ} \mathrm{F}(980 \mathrm{~K})$; total strain range, 4 percent. (Creep rates measured at 10 cycles.)

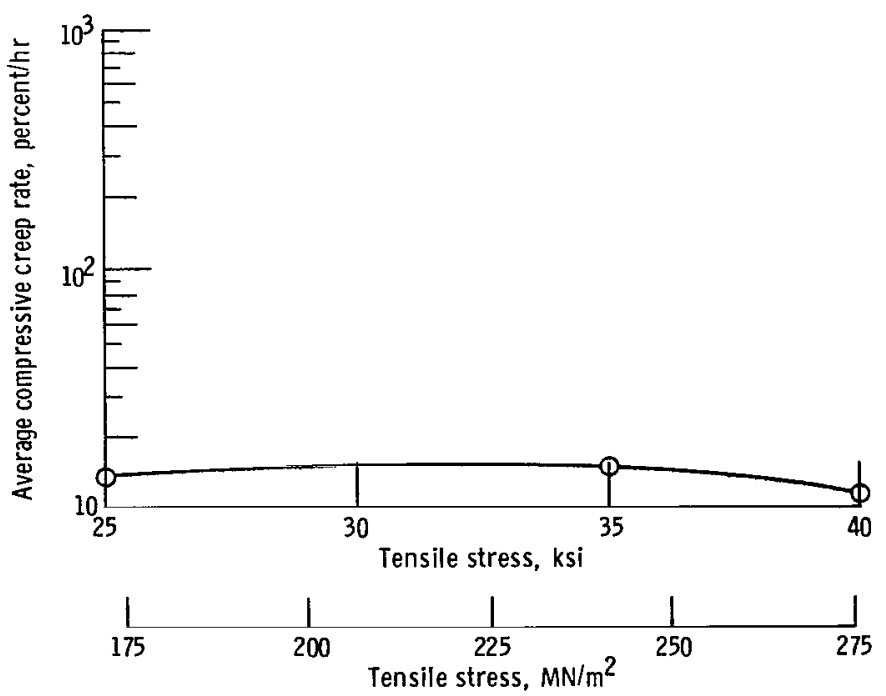

Figure 8. - Effect of tensile stress on compressive creep rate at compressive stress of $35 \mathrm{ksi}\left(240 \mathrm{MN} / \mathrm{m}^{2}\right)$ for fully annealed $316 \mathrm{stain}$ less steel. Test temperature, $1300^{\circ} \mathrm{F}(980 \mathrm{~K})$; total strain range, 4 percent. (Creep rates measured at 10 cycles.) 


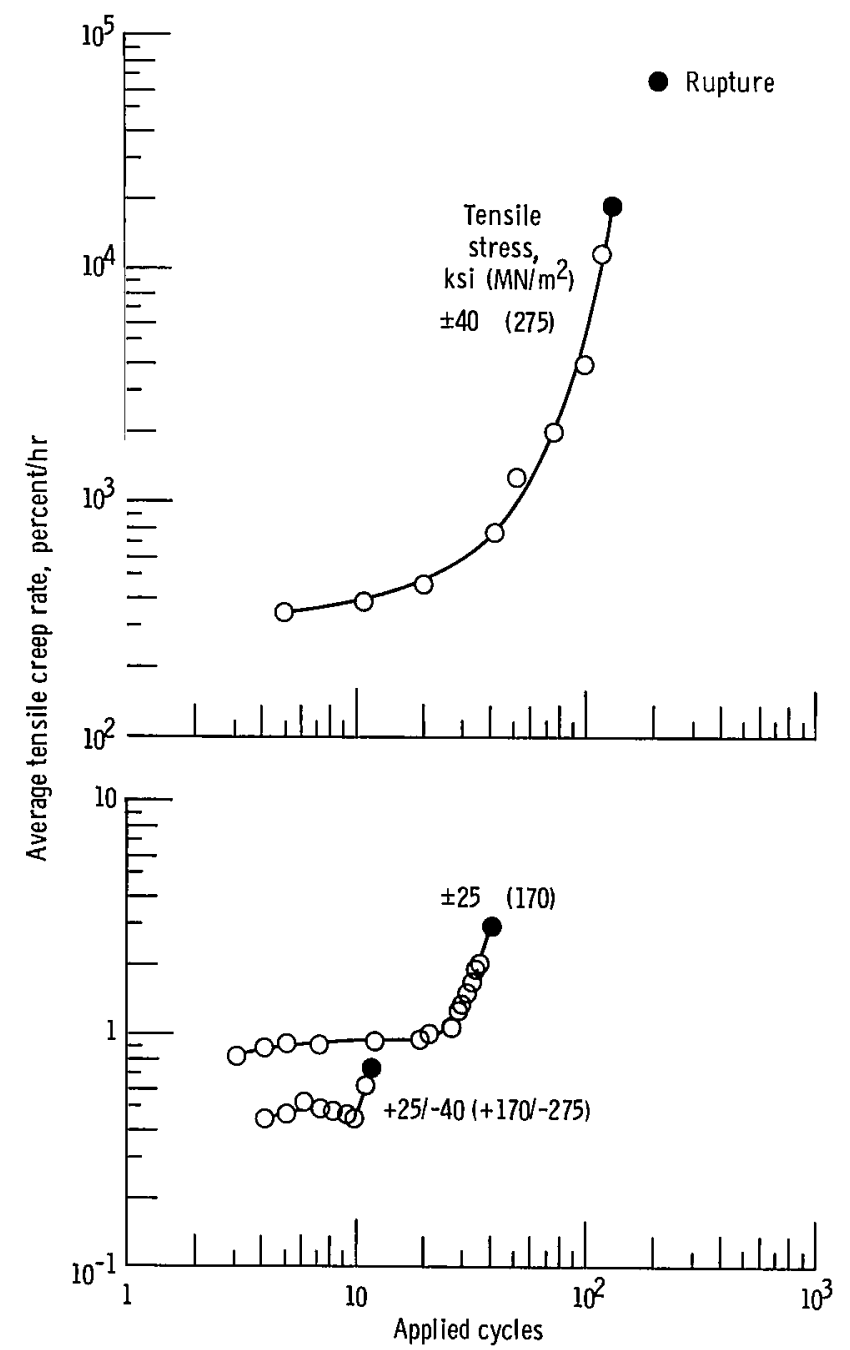

Figure 9. - Creep acceleration during cyclic creep-rupture testing of fully annealed 316 stainless steel. Test temperature, $1300^{\circ} \mathrm{F}$ $(980 \mathrm{~K})$; total strain range, 4 percent.

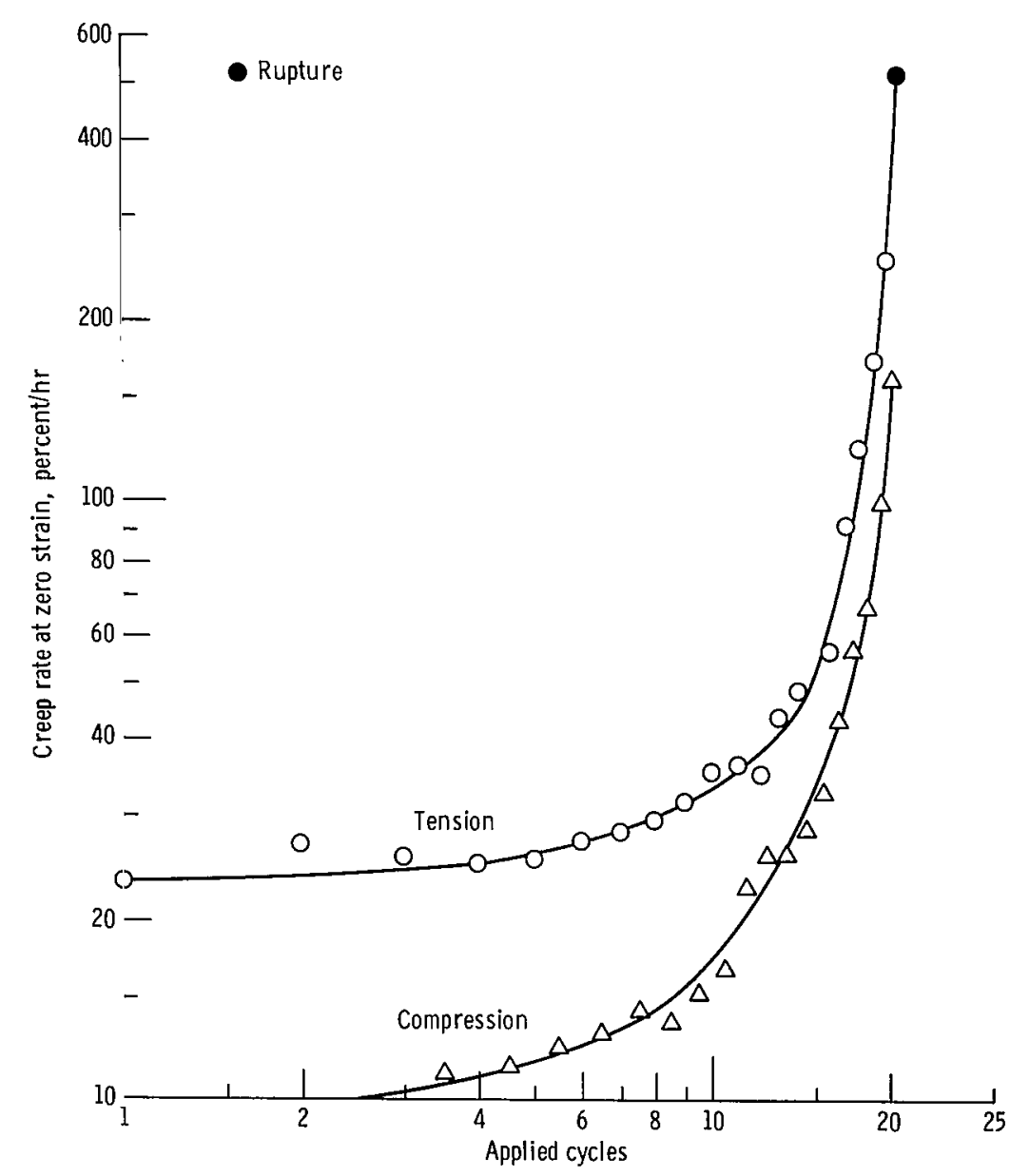

Figure 10. - Creep acceleration du ring cyclic creep-rupture testing of partially annealed 316 stainless steel. Test temperature, $1300^{\circ} \mathrm{F}(980 \mathrm{~K})$; total strain range, 9 percent; stress, $\pm 45 \mathrm{ksi}\left(310 \mathrm{MN} / \mathrm{m}^{2}\right)$. 
National Aeronautics and Space administration

WASHINGTON, D. C. 20546

OFFICIAL BUSINESS

FIRST CLASS MAIL

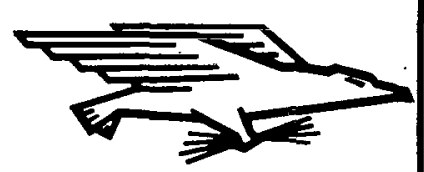

POSTAGE AND FEES PAID NATIONAL AERONAUTICS AND SPACE ADMINISTRATION
O5U $00142 \quad 5130 S$ AIR FORCE WEAPONS LABORATORY /WLOL/ KIRTLAND AFB, NEW MEXICO 87117

ATT E. LOU BOWMAN, CHIEF, TECH. LIBRARY

POSTMASTER: If Undeliverable (Secrion 158 Postal Manual) Do Not Return

"The aeronautical and space activities of the United States shall be conducted so as to contribute . . to the expansion of buman knowledge of phenomena in the atmosphere and space. The Administration shall provide for the widest practicable and appropriate dissemination of information concerning its activities and the results thereof."

- National AeronaUtics AND SpaCe ACt of 1958

\section{NASA SCIENTIFIC AND TECHNICAL PUBLICATIONS}

TECHNICAL REPORTS: Scientific and technical information considered important, complete, and a lasting contribution to existing knowledge.

TECHNICAL NOTES: Information less broad in scope but nevertheless of importance as a contribution to existing knowledge.

TECHNICAL MEMORANDUMS:

Information receiving limited distribution because of preliminary data, security classification, or other reasons.

CONTRACTOR REPORTS: Scientific and technical information generated under a NASA contract or grant and considered an important contribution to existing knowledge.
TECHNICAL TRANSLATIONS: Information published in a foreign language considered to merit NASA distribution in English.

SPECIAL PUBLICATIONS: Information derived from or of value to NASA activities. Publications include conference proceedings, monographs, data compilations, handbooks, sourcebooks, and special bibliographies.

\section{TECHNOLOGY UTILIZATION}

PUBLICATIONS: Information on technology used by NASA that may be of particular interest in commercial and other non-aerospace applications. Publications include Tech Briefs, Technology Utilization Reports and Technology Surveys.

Details on the availability of these publications may be obtained from:

SCIENTIFIC AND TECHINICAL INFORMATION OFFICE

NATIONAL AERONAUTICS AND SPACE ADMINISTRATION

Washington, D.C. 20546 